\title{
A COMPARATIVE ANALYSIS OF MARKETING STRATEGIES ADOPTED BY SPECIALISED AND DEPOSIT MONEY BANKS IN OYO STATE NIGERIA
}

\section{Oluwaseun Joseph Akanji and Amos Sola Ogunsiji}

\author{
Department of Marketing, Ladoke Akintola University of Technology, Ogbomoso, Oyo \\ State, Nigeria
}

Cite this article:

Oluwaseun J.A., Amos S.O. (2021), A Comparative Analysis of Marketing Strategies Adopted by Specialised and Deposit Money Banks in Oyo State Nigeria. British Journal of Management and Marketing Studies 4(2), 60-70. DOI: 10.52589/BJMMS-

EZ1KP6LU.

\section{Manuscript History}

Received: 27 April 2021

Accepted: 18 May 2021

Published: 22 May 2021

Copyright $\odot 2020$ The Author(s). This is an Open Access article distributed under the terms of Creative Commons AttributionNonCommercial-NoDerivatives 4.0 International (CC BY-NC-ND 4.0 ), which permits anyone to share, use, reproduce and redistribute in any medium, provided the original author and source are credited.
ABSTRACT: Nigerian banking system is characterized by internal and external competition. The upsurge of new banks created room for innovation and further market sharing. A proxy to determine the extent of competition is the intensity of marketing strategies adopted by these banks in recent times. The strategies utilized by Specialized and Deposit Money Banks have been a subject of inquiry on whether they are alike or not. This work against the identified gaps, therefore, compares the marketing strategies adopted by specialized and deposit money banks and as well examines the effect of service quality management on performance of these banks. Data was collected through a selfadministered questionnaire from a number of 102 bank staff in six purposely selected specialized and deposit money banks in Oyo state. SPSS was employed to aid the data analysis. Having analyzed the data, the study found out that there is an insignificant difference between the marketing strategies (promotion strategy, customer relationship management strategy and service quality) adopted by specialized and deposit money banks. Guided by the findings, the study recommended that new entrants going into banking and other financial institutions should stick to the various marketing strategies under the study with the most focus on service quality management. The work also offers that specialized banks need to have assurance, which refers to knowledge and courtesy of employees and their ability to inspire trust and confidence.

KEYWORDS: Marketing Strategies, Specialized Banking, Corporate Performance, Deposit Money Banks 


\section{INTRODUCTION}

In today's competitive, fast-paced and global economy, there is a growing demand especially for service driven firms for practical guidelines in developing a customer focus. Drucker (1977) observes that the key business purpose is to create a customer. He further argues that a firm's ability to remain in business is a function of its competitiveness and its ability to win customers from the competition. This position is further reinforced by Cook (2002) who gives more emphasis not only on customer attraction fronted by Drucker (1997) but additionally, a high level of customer retention. Cook advised that a firm's ability to attract and retain new customers is a function of both the product offering and the way it services its customers and the resultant reputation it creates within and across the industry. Business organizations have to contend with the dynamics of a changing competitive environment. The modern trend has shifted from external environmental analysis to more sophisticated internal organizational analysis. All forms of businesses, including those in the banking industry, regardless of their size or level of development have embraced strategies to survive (Greenstein, 2008). Due to stiff competition and changing consumer needs in the banking industry, organizations have to formulate and implement strategies that will enable them to minimize customer service breakdown thus attracting and retaining them (Porter, 2004).

Strategy is the long-term direction, which organizations adopt to gain competitive edge in the dynamic business environment by using resources and core competencies to fulfill stakeholder expectations (Johnson Scholes and Whittington 2005). A company's strategy consists of the business approaches and initiatives it undertakes to attract customers and fulfill their expectations, to withstand competitive pressures and to strengthen its market position. These strategic responses provide opportunities for the organization to respond to the various challenges within its operating environment. Firms also develop strategies to enable them seize strategic initiatives and maintain a competitive edge in the market (porter, 2004). The competitive aim is to provide satisfactory customer service. The success of every organization is determined by its responsiveness to the customer needs. Any organization cannot operate without a strategy because "strategy formulation" is vital to the well-being of an organization (Yunggar, 2005). Strategic reactions to the external environment of the organization are crucial to the success of any company. Every successful business has a plan and knows where it is heading in the future. Taking the time on an ongoing basis to review the company's past performance, and predict its future performance, gives it a road map to follow.

Thompson (2003) mentioned that "the most important elements of development which would greatly influence the strategies, structure and performance of the future companies include: economic relations, business performance would be more and more a matter of strategic joint venture, which would be integrated into a world economy. Restructuring of business would be intensified and there will be more globalization. It would be important to have information and knowledge as strategic management of companies would be decisive for a competitive success. Intensive market orientation of companies would be a core advantage for achieving a competitive advantage over competitors". The competitive aim of any strategic organization is to do a significantly better job of providing what customers are looking for, thereby enabling the company to earn a competitive advantage and outsmart rivals in the market place. The core of a company's strategy consists of its internal initiatives to deliver satisfaction to customers but also includes offensive and defensive moves to counter the maneuvering of rivals, actions to shift resources around to improve the firm's long term competitive capabilities and market position, and tactical efforts to respond to prevailing market conditions. Assuming that there 
are a number of providers, customers will choose which offering to accept based on their perception of value-for-money (Akinboboye, 2007).

Given the trend of every aspect of economic activities globally and particularly Nigeria, it is imperative for business entities to adopt measures that should strategically reposition them so as to remain afloat. With much increase in the level of customer awareness in response to their needs and wants or satisfaction, firms should also discuss their old marketing strategies that are not result-oriented. They should acknowledge the paradigm shift from the old marketing concept to the new marketing concept, which is a customer driven, technology-driven era in modern marketing management (Johnson, 1990). One of the industries which has gradually started repositioning its operation to suit customer's needs and wants is the banking industry.

Nigerian banking system is characterized by internal and external competition. The upsurge of new banks created room for innovation and further market sharing. A proxy to determine the extent of competition is the intensity of advertising by banks in recent times. The system has witnessed sophistication in the style and designing of new financial products (Anyafo, 1999), concluding the charting of the prospects of the banking industry in Nigeria for the 1980s and beyond. Vincent (1980) envisaged that the service demanded of the banking industry will become more sophisticated in response to change in the nature of the business they are called upon to finance and as their customers become more knowledgeable and discriminating. It is in the light of the above problems that this study seeks to determine the relationship between marketing strategies and performance adopted by specialized and deposit money banks in Oyo state, Nigeria. Thus, this study assesses the degree of adoption and continuous use of marketing strategies as an instrument of achieving competitive advantage in the banking industry in Oyo state, Nigeria. Hence, the study (i) compares the marketing strategies adopted by specialized and deposit money banks (ii) examines the effect of service quality management on performance.

\section{REVIEW OF THE LITERATURE}

\section{Conceptual Framework}

\section{Concept of Marketing Strategy}

McCharthy (2011) opines that a marketing strategy specifies a target market and a related marketing mix. It is a big picture of what a firm will do in some market. Two interrelated parts are needed: (1) a target market that is a fairly homogeneous (similar) group of customers to whom a company wishes to appeal; and (2) a marketing mix that is the controllable variables the company puts together to satisfy this target group. Cravens (2009) states that strategy consists of the analysis, strategy development, and implementation of activities in: developing vision about the markets of interest to organization, selecting market target strategies, setting objectives, and developing, implementing, and managing the marketing program positioning strategies designed to meet the value requirements of the customers in each market target. Kotler and Amstrong (2012) defines marketing strategy as the marketing logic by which the company hopes to create customer value and achieve profitability and customer relationship. Mooradian (2012) states that marketing strategy specifies the who, what, when, where, why, and how the business: (1) Who the firm will serve - the customers and segments the business will serve; (2) When the firm will serve the customers and those needs - that is, what 
"occasion" the firm will target; (3) Where the firm will do business - the geographic markets the firm will serve; (4) What needs the firm will meet; (5) How the firm will serve those customers and needs-the means (resources and distinctive competencies) the firm will bring to bear to serve those customers and their needs better than competition; and (6) Why the firm will do these things - the compelling business model that specifies how long term revenues will exceed costs by reasonable rate of return on the capital employed. Mooradian (2012) said that strategy formulation and implementation is: (1) segmenting, targeting, positioning (STP); (2) marketing mix; and (3) customer relationship management (CRM).

Kotler and Keller (2012) dan Levy and Grewal (2008) state that an effective marketing requires marketers to: identify and determine the profile of various groups of the buyers who have needs and preferences (segmentation/ market segmentation), choose one or more segments market should go in the determination of market (targeting or market targeting), and for each segment of the target market determine and communicate many benefits market offering company (positioning/ market positioning). Cravens (2009) states that the process of market segmentation identifies market segments, the formation of market segments (forming market segments), segmentation (find strategy approach of various strategies segmentation), selecting strategy and the segmentation (segmentation strategy). Cravens (2009) Kotler and Keller (2012) opine that the determination of target market (market targeting) is an activity that is carried out after we can perform segmentation of all different market potential, then the company must decide what kind of and how many segments that will be targeted. Target market consists of a number of buyers who share the needs and characteristics that will be served by the company. The process of selection of the segment where we are going to offer our products and services are known by the term targeting.

The company can choose a covering market as follows: full market coverage, multiple segment specialization, single segment concentration, and ethical choice of market targets. Cravens (2012) opines that the positioning strategy is the combination of marketing program (mix) strategies used to portray the positioning desired by management to the targeted buyers. The decision of the election of the target market is a central point of the strategy of marketing itself and became the basis in determining the purpose and development strategy positioning. Because of it, positioning strategy is the main factor in increasing the power of the company's market position in a particular market than their competitors. So positioning is a business to infuse an impression (image) specifically in mind of consumers to products even against the company target. Kotler and Amstrong (2012) state that the positioning is the act of designing the company's offer so that it occupies a distinct and value placed in the target customer mind.

\section{Performance}

Performance defined using the 3E: efficiency, efficacy and economies, as forms of manifestation. MihaiRistea (2002) thinks that the following three concepts can be associated with performance: efficiency, economies and efficacy. It can be noticed that an entity is successful when it is efficient, effective and economical. Therefore, to be successful means combining all three variables, the combination of which reflects the performance level of an entity. Efficiency consists in either using a quantity given by resources, aimed at the highest level of the achieved results, or reducing the quantity of the used resources with the aim of achieving a predetermined result. Economies consist in providing the means, the necessary resources to performing an activity at the minimum cost. Efficacy is determined by achieving or exceeding the predetermined results to the actual results made throughout the development 
of the activity. This represents the ability of the enterprise to meet and even exceed the expectations of users of the accounting information (shareholders/associates, clients, suppliers, employees, government) at the same time with reaching the predetermined organizational objectives. An entity reaches efficacy when it manages to improve the way of using all sources which are available and necessary to the development of the activity, performing as well as possible the needs and the requirements of the external partners of the organization.

\section{Theoretical Anchor}

This work hinges on marketing mix theory. According to Gronroos (1994), the theory of Marketing Mix was coined by Borden. The theory is still used till today to make important decisions that lead to the execution of a marketing plan. The idea of a marketing mix theory is to organize all aspects of the marketing plan around the habits, desires and psychology of the target market. Marketing mix theory combines a number of components in order to strengthen and solidify a product's brand and help to sell the product or service. The components combined by this are products, price, promotion and place forming the four P's are the parameters that the marketing manager can control, subject to the internal and external constraints of the marketing environment. The goal is to make decisions that centers the four P's on the customers in the target market in order to create perceived value and generate a positive response.

\section{METHODOLOGY}

This study adopted a survey design. The data used for this research was obtained specifically from primary source which involved using questionnaire to collect data for research questions. The study population comprised of 102 bank staff in six purposively selected specialized and deposit money banks in Oyo state. The targeted population strictly comprised of highly performing banks according to net profit and running cost. Having defined the population, the researcher made use of the entire population because it was few. The survey technique adopted for this research is census. The responses opinion was tried with percentages, while t-test and regression analysis were used to test the formulated hypotheses. The instrument was validated through face validity and the result of reliability test shows an overall Cronbach Alpha of 0.83 , indicating high reliability of the instrument. Altogether, one hundred and two copies of questionnaire were printed and directed to the banks marketing staff. The questionnaire was divided into two sections - A and B. Section A addressed the respondents biographical and psycho graphical data while section $\mathrm{B}$ addressed questions relating to the objectives of the research.

\section{RESULTS AND FINDINGS}

There was a perfect return rate regarding the questionnaire. In all, 102 copies of the questionnaires were administered to the respondents, and all were returned with none filled incorrectly nor head back. Therefore, the data collected from the field is deemed adequate enough for the study. 
British Journal of Management and Marketing Studies

ISSN: 2689-5072

Volume 4, Issue 2, 2021 (pp. 60-70)

www.abjournals.org

Table 1: Distribution of the respondents according to the types of Bank

\begin{tabular}{c|cc}
\hline Parameters & Frequency & Percent \\
\hline Deposit money bank & 79 & 78.2 \\
Specialized bank & 22 & 21.8 \\
\hline
\end{tabular}

Source: Author's Computation, 2020

Table 2: Specific distribution of the respondents according to the types of Bank

\begin{tabular}{c|cc}
\hline Parameters & Frequency & Percent \\
\hline Bank of Agriculture & 7 & 6.9 \\
Bank of Industry & 8 & 7.9 \\
FCMB & 23 & 22.8 \\
Federal Mortgage Bank & 7 & 6.9 \\
Stanbic IBTC & 24 & 23.8 \\
Union Bank & 32 & 31.7 \\
\hline
\end{tabular}

Source: Author's Computation, 2020

Objective 1: Marketing Strategies adopted by specialized banks and deposit money banks

Table 3 compares the marketing strategies adopted by the specialized and deposit money banks. Looking into how prompt their responses are to customers' complaint between the specialized bank and deposit money bank, a humongous $79 \%$ disagreed and 17\% strongly disagreed that prompt responses are not better than the deposit money banks. Going further, examining whether Specialized banks have customer service units that manage customers' issues and complaints rather than deposits money banks with no unit, 54\% of the respondents disagreed and $43 \%$ strongly disagreed to that and a minute number of $1 \%$ strongly agreed and $3 \%$ agreed. The respondents disagreed significantly to the customer service of the Specialized bank over that of the deposit money bank. Overall, this table shows the lapses of the specialized banks that can be improved upon.

Table 3: Comparing Marketing Strategies Adopted by specialized and Deposit Money Banks

\begin{tabular}{l|llll}
\hline $\begin{array}{l}\text { Comparing Marketing Strategies Adopted by } \\
\text { specialised and Deposit Money Banks }\end{array}$ & $\begin{array}{c}\text { Strongly } \\
\text { Agree }\end{array}$ & Agree & Disagree & $\begin{array}{l}\text { Strongly } \\
\text { Disagree }\end{array}$ \\
\hline $\begin{array}{l}\text { Prompt response to customer complaints are handled in } \\
\text { specialized banks than in deposit money banks }\end{array}$ & $3(3.0)$ & $2(2.0)$ & $79(78.2)$ & $17(16.8)$ \\
$\begin{array}{l}\text { Specialized banks have customer service units that } \\
\text { manage customers' issues and complaints rather than } \\
\text { deposits money banks with no unit }\end{array}$ & $1(1.0)$ & $3(3.0)$ & $54(53.5)$ & $43(42.6)$ \\
\hline
\end{tabular}


British Journal of Management and Marketing Studies

ISSN: 2689-5072

Volume 4, Issue 2, 2021 (pp. 60-70)

www.abjournals.org

There is the ability of specialized banks to perform their $\quad 0(0.0) \quad 3(3.0) \quad 38(37.6) \quad 60(59.4)$

service more reliable and effective than the deposit

money banks

Specialized banks are often willing to assist customer's

and provide prompt service than deposit money banks

Public relations are not adequately used in specialized

banks the way deposit banks use it

Advertising and sales promotion are used in specialized

than in deposit money banks

Competitors are often considered when setting the price

of product/service in specialized than in deposit money

banks

Source: Author's Computation, 2020

\section{Objective 2: Performance and Service Quality Management}

Table 4 shows that the banks have excellent service quality management as the customers are duly almost always satisfied but we still have a few people who disagree and are uncertain. The question does your bank promptly and willingly responds to customers complaints $73.3 \%$ respondents strongly agreed and $25.7 \%$ respondents agreed that they are swiftly responded to but a minute $1 \%$ was uncertain. $35.6 \%$ strongly agreed and $62.4 \%$ agreed that there is a customer service section in their bank but $2 \%$ strongly disagreed. Furthermore $50.5 \%$ strongly agreed and $48.5 \%$ agreed that the bank is always looking for means to assist their customerswhen they have issues while $1 \%$ disagree. Lastly, $56.4 \%$ of respondents strongly agreed and $40.6 \%$ agreed that the desire of the bank to render assistance is of the utmost importance while $2 \%$ was uncertain and $1 \%$ disagreed.

\section{Table 4: Service Quality Management}

\begin{tabular}{|c|c|c|c|c|c|}
\hline Service Quality Management & $\begin{array}{l}\text { Strongly } \\
\text { Agree }\end{array}$ & Agree & Uncertain & Disagree & $\begin{array}{l}\text { Strongly } \\
\text { Disagree }\end{array}$ \\
\hline $\begin{array}{l}\text { Your bank promptly and willingly } \\
\text { responds to customers complaints }\end{array}$ & $74(73.3)$ & $26(25.7)$ & $1(1.0)$ & $0(0.0)$ & $0(0.0)$ \\
\hline $\begin{array}{l}\text { There is a customer service section } \\
\text { in your bank }\end{array}$ & $36(35.6)$ & $63(62.4)$ & $0(0.0)$ & $0(0.0)$ & $2(2.0)$ \\
\hline $\begin{array}{l}\text { Your bank is always looking for } \\
\text { means to assist their customers } \\
\text { when they have issues }\end{array}$ & $51(50.5)$ & $49(48.5)$ & $0(0.0)$ & $1(1.0)$ & $0(0.0)$ \\
\hline $\begin{array}{l}\text { The desire to render adequate } \\
\text { assistance to customers' is your } \\
\text { bank's utmost importance }\end{array}$ & $57(56.4)$ & $41(40.6)$ & $2(2.0)$ & $1(1.0)$ & $0(0.0)$ \\
\hline
\end{tabular}

Source: Author's Computation, 2020 


\section{Performance}

Table 5 displays the performance of the types of banks surveyed. In terms of the banks' swift response to customers' complaints leading or yielding to higher patronage $76.2 \%$ strongly agreed, $21.8 \%$ also agreed but a negligible $1 \%$ disagreed and another $1 \%$ strongly disagreed. Also examining the relationship between banks and its customers as a pedestal to a significant level of growth and performance $43.6 \%$ of the respondents strongly agreed and $53.6 \%$ also agreed but a minute amount of respondent of $1 \%$ disagreed and $2 \%$ strongly disagreed. Looking further if effective marketing strategies have helped increase the profitability position of the banks $43.6 \%$ strongly agreed that it has $32.7 \%$ also agreed that it has but $2 \%$ was uncertain and $10.9 \%$ disagreed and $10.9 \%$ strongly disagreed. Also, $41.6 \%$ of respondents strongly agreed and 55.4\% agreed that their bank has witnessed an increase in sales of products and demand for services due to marketing strategies but $2 \%$ disagreed and $1 \%$ strongly disagreed. Lastly, $51.5 \%$ strongly agreed and $25.7 \%$ agreed that the application of marketing strategies has made your bank to be more competitive but $2 \%$ were uncertain and $8.9 \%$ disagreed and $11.9 \%$ strongly disagreed.

Table 5: Performance

\begin{tabular}{|c|c|c|c|c|c|}
\hline Performance & $\begin{array}{l}\text { Strongly } \\
\text { Agree }\end{array}$ & Agree & Uncertain & Disagree & $\begin{array}{l}\text { Strongly } \\
\text { disagree }\end{array}$ \\
\hline $\begin{array}{l}\text { Your bank's swift response to } \\
\text { customers' complaints yielded high } \\
\text { patronage }\end{array}$ & $77(76.2)$ & $22(21.8)$ & $0(0.0)$ & $1(1.0)$ & $1(1.0)$ \\
\hline $\begin{array}{l}\text { The relationships between your } \\
\text { bank and its customers have led to } \\
\text { a significant level of growth and } \\
\text { performance }\end{array}$ & $44(43.6)$ & $54(53.6)$ & $0(0.0)$ & $1(1.0)$ & $2(2.0)$ \\
\hline $\begin{array}{l}\text { With effective marketing } \\
\text { strategies, your bank has } \\
\text { increased its profitability position }\end{array}$ & $44(43.6)$ & $33(32.7)$ & $2(2.0)$ & 11(10.9) & 11(10.9) \\
\hline $\begin{array}{l}\text { Your bank has witnessed an } \\
\text { increase in sales of products and } \\
\text { demand for services due to } \\
\text { marketing strategies }\end{array}$ & $42(41.6)$ & $56(55.4)$ & $0(0.0)$ & $2(2.0)$ & $1(1.0)$ \\
\hline $\begin{array}{l}\text { Application of marketing } \\
\text { strategies has made your bank to } \\
\text { be more competitive }\end{array}$ & $52(51.5)$ & $26(25.7)$ & $2(2.0)$ & $9(8.9)$ & $12(11.9)$ \\
\hline
\end{tabular}

Source: Author's Computation, 2020

\section{Correlation Analysis}

\section{Objective 1: Marketing Strategies adopted by specialized banks and deposit money banks}

In order to ascertain the Marketing Strategies adopted by Deposit Money Bank and Specialized Bank, the indicators of marketing strategy in the questionnaire were pre-processed and 
analyzed using independent Sample T-test. According to the result in Table 6, there is no significant difference between Deposit Money Bank and Specialized Bank with t-statistics of -0.705 and $\mathrm{P}$-value of 0.483 . The result indicates that the three marketing strategies (promotion strategy, customer relationship management strategy and service quality management) examined between specialized and deposit money banks are fully adopted. As a result of the findings, we therefore accept the alternate hypothesis that there is a significant relationship between the marketing strategies adopted by specialized bank and deposit Money banks and reject the null hypothesis.

Table 6: Deposit Money Bank and Specialized Bank

\begin{tabular}{l|ll}
\hline Marketing Strategy & Mean & $\boldsymbol{t}($ Sig $)$ \\
\hline Deposit Money Bank & 4.4014 & $-0.705(0.483)$ \\
Specialized Bank & 4.4545 &
\end{tabular}

Source: Author's Computation, 2020

\section{Objective 2: Performance and Service Quality Management}

The effect of Service Quality Management (SQM) on Performance (PERF) considering both Deposit money banks and specialized banks for this study is determined using simple linear regression. As presented in Table 14, it is seen that the Deposit money bank model is significant with F-stat and P-value of 56.218 and 0.000 respectively at $1 \%$ level of significance and for Specialized bank, 3.063 (F-stat) and 0.095 (P-value) at 10\% level of significance. This implies that we could draw explanations of changes in Performance from Service Quality Management (SQM) for this study.

For a Deposit money bank, Service Quality Management (SQM) is seen to be strongly significant at $1 \%$ with Performance (PERF) [coef:0.824, P-value: 0000]. This implies that a unit change in the SQM will cause a corresponding positive change in the Performance of the bank. Also, slightly different results is displayed with the Specialized bank having SQM statistically significant but at $10 \%$ level and a negative coefficient [coef:-0.671, P-value: 0.095]. This can be interpreted as for a unit change in SQM, there would be an equivalent negative (decrease) change in performance (PERF).

The null hypothesis that states that there is no significant effect of Service Quality Management (SQM) on Promotion is therefore rejected and it implies that Service Quality Management significantly affects performance for both Deposit Money Bank and Specialized Bank. The result of the study is in harmony with the research conducted by (Benta, 2016) which also found that service quality has a significant influence on the performance of banks. It implies that one of the most effective strategies banks and other financial institutions can deploy is service quality management.

Any significant deviation from this particular strategy will automatically bring an instability to the overall well-being of the organization. 
Table 14: Performance and Service Quality Management

\begin{tabular}{l|ll}
\hline & Deposit Money Bank & Specialized bank \\
\hline Model [F-stat $(P$-value $)]$ & $56.218(0.000)$ & $3.063(0.095)$ \\
SQM [coef $(P$-value $)]$ & $0.824(0.000)$ & $-0.671(0.095)$ \\
\hline
\end{tabular}

Source: Author's Computation, 2020, SQM = Service Quality Management, PERF = Performance

\section{CONCLUSION AND RECOMMENDATIONS}

Specific findings of the current research have demonstrated several relevant conclusions on the comparative analysis of marketing strategies between specialized and deposit money banks, as well as the evaluation of the impact of marketing strategies on the performance of both banks.

Based on the findings, the study concluded that there is an insignificant difference between the marketing strategies (promotion strategy, customer relationship management strategy and service quality) adopted by specialized and deposit money banks. In addition, the study concluded that Service Quality Management significantly affects performance of both Deposit Money Banks and Specialized Banks.

Based on the findings and study conclusion, it is being recommended that;

i. On the basis of finding from this study where there is insignificant difference between Deposit Money Bank and Specialized Bank with t-statistics of -0.705 and P-value of 0.483 , the study recommends that the new entrants going into banking and other financial institutions should stick to the various marketing strategies under study with the most focus on service quality management.

ii. Findings revealed that there is a strong significant relationship between service quality and performance of the banks under study. Therefore, the study recommends that industry players should dwell on the service quality by improving the response time to customers complaints and provision of more customer service section within and outside the banks.

iii. Also, the study recommends for specialized banks; assurance, which refers to knowledge and courtesy of employees and their ability to inspire trust and confidence

Although this present research work compared the marketing strategies between deposit money banks and specialized banks and evaluated the impact of strategies on performance. However, there are many potential benefits of marketing strategies that are yet to be empirically investigated. One of such areas, which requires examination is the extent to which segmentation, targeting and positioning influence performance. 


\section{REFERENCES}

Akinboboye, O.D. (2007),Factors influencing the internationalization of Nigerian Banks. Lagos: Lifeline Prints

Anyanfo, M. (1999). Team Work in Modern Organizations: Implications for Technological behavior, and motivation. Journal of Consumer Research, 29, 280-285.

Cook, S. (2002). Customer Care Excellence: How to Create an Effective Customer Focus. London, UK.: Kogan Page Limited.

Cravens, S. (2009). Bypassing the will: Toward demystifying the nonconscious control of Education. International Journal of Technology and Design Education 9: 85-101

Dan Levy and Grewal (2008). Marketing. $6^{\text {th }}$ Edition. McGraw-Hill

Drucker P. (1977) Imperative of Strategies to Manufacturing firms: an empirical analysis", International Journal of Business and Management Science. 21(2), 160-171.

Greenstein, W., (2008). Marketing Behavior and Executive Action: A Functionalist Approach New York, NY: Oxford University Press.

Johnson, S., and Whittington, M. N. (2005), "Critical success factors in business performance. Management Research 1(3), 14-34.

Kotler and Keller (2012) Marketing Management. 14th Edition, Pearson Education.

Kotler, P., and Armstrong, G. (2012). Principles of Marketing. $14^{\text {th }}$ edition. London: Pearson Education.

McCarthy, T. M. (2011). Losing consciousness: Automatic influences on consumer judgment, social behavior. In R. R. Hassin, J. S. Uleman, and J. A. Bargh (Eds.), The New Unconscious management-Striving for success, Information Systems Management, 25(2), 113-120

Mooradian, O. (2012). The unbearable automaticity of being. American Psychologist, 54, $462-479.28$

Porter, M. (2004) Marketing and the bottom line: the marketing metrics to pump up cash flow. 2. ed. Norfolk: Prentice Hall.

Thompson, V. (2003). Solving the Marketing Mix Problem Using Geometric Programming. to Marketing Theory. Home-wood, IL: Richard D. Irwin, Inc.

Yungaar, O. (2005), "Strategic marketing orientation and performance: a case for synergistic merger effects of Nigerian banks", European Journal of Scientific Research, 42(2), 268-289. 